\title{
An Empirical Study on Innovation Ecosystem, Technological Trajectory Transition, and Innovation Performance
}

\author{
Yu Sun, School of Management, Hangzhou Dianzi University, China \\ Ling Li, Department of Information Technology and Decision Science, Old Dominion University, USA \\ Yong Chen, A. R. Sanchez, Jr. School of Business, Texas A\&M International University, USA \\ Mikhail Yu Kataev, Department of Control Systems, Tomsk State University of Control Systems and Radioelectronics, \\ Russia
}

\begin{abstract}
This paper explores technological trajectory transition in the perspective of innovation ecosystem and their effect on innovation performance of latecomers in market. A structural equation model is developed and tested with data collected from 366 firms in China. In specific, this paper categories technological trajectory transition creative accumulative technological trajectory transition (CCT) and creative disruptive technological trajectory transition (CDT). The results indicate that firms' organizational learning ability positively affect their technological trajectory transition and innovation performance. Firms' network relationship strength negatively affects their technological trajectory transition and positively affect their innovation performance. Governments' environmental concerns positively affect firms' technological trajectory transition and their innovation performance, whereas firms' environmental concerns do not. CCT does not positively affect their innovation performance. In contrast, CDT positively affects their innovation performance.
\end{abstract}

\section{KEYWORDS}

Innovation Ecosystem, Innovation Performance, Technological Trajectory Transition

\section{INTRODUCTION}

In emerging economies, firms face a dilemma: continuing the low-cost and imitation-based competitive strategy or enhancing R\&D to become leaders in innovation (Cao et al 2019; Chaudhry et al 2018; Hobday, et al., 2004; Xiao, et al., 2013). Recently, some industries in emerging economies have obtained global competitiveness via low labor costs. They achieved technological progress through technology introduction, absorption, and re-innovation. However, when firms in emerging economies try to catch up the industrial leaders for reducing the technological gap, sudden technological changes initiated by the industrial leaders cause these firms to fall behind again. Therefore, it is difficult for firms in emerging economics to follow the technological trajectories established by industrial leaders. As a result, technology leapfrogging becomes an option for firms in emerging economics to realize technology catchup (Lei, Lin, Sha 2016). Latecomers can catch up with industrial leaders through leapfrogging some phases of technological trajectories or creating new trajectories. 
Adner and Kapoor (2015) point out that social-economic factor, such as institution, social concerns, industrial organization, and power allocation, play an important role in technological transition. However, they did not examine the mechanism how these factors affect technological transition. How socio-economic factors affect firms' strategies in technology catching up and their innovation performance remains unknown. Accordingly, this paper categories technological trajectory transition into creative accumulative technological trajectory transition (CCT) and creative disruptive technological trajectory transition (CDT). It further proposes a theoretical framework to explore the relationship among innovation ecosystem, technological trajectory transition, and innovation performance. Particularly, this paper applies structural equation modeling to examine how some key socio-economic factors, namely organizational learning ability, network relationship strength, and environmental concerns, affect firms' technological trajectory transition. Moreover, it examines how these factors and technological trajectory transition affect firms' innovation performance.

Data collected from 366 firms in China is applied to examine the research model. The results indicate that that firms' organizational learning ability positively affects their CCT, CDT, and innovation performance. Firms' network relationship strength negative affects their CCT and CDT, whereas positively affect their innovation performance. Governments' environmental concerns positively affect firms' CCT, CDT, and innovation performance. Firms' environmental concerns do not positively affect their CCT, CDT, and innovation performance. Firms' CCT does not positively affect their innovation performance. In contrast, firms' CDT positively affects their innovation performance.

Other than enriching the theories of technological trajectory, this paper provides implications for managers and policy-makers in emerging economies. In specific, it provides guidance on how to make strategic choices when facing different technology development paths, and on how to implement technological trajectory transition.

The remainder of this paper is organized as follows. We review relative literature in Section 2. We develop a research model and propose hypotheses in Section 3. We describe the research methodology and measurements in Section 4. Section 5 analyzes the structural equation model and discusses the empirical results. Section 6 summarizes the findings, outlines the managerial implications, discusses the limitations of our research, and points out directions for future research.

\section{LITERATURE REVIEW}

\subsection{Innovation Ecosystem}

Traditional innovation (Innovation 1.0) is inbound closed. Technological progress, global competition, and ecology development have driven innovation paradigm to evolve from inbound closed innovation to ecosystem network innovation (Innovation 2.0) (Rupčić, Majić, Stjepandić 2020), and then to embedded innovation (Innovation 3.0), which highlights resource integration (Xu, Cai, Zhao and Ge 2016) and symbiotic development (Li, et al., 2014).

According to Zhao and Zeng (2014), an innovation ecosystem can be seen as a self-organized evolution system that is associated with environment dynamically. It consists of members that evolve together, including firms, consumers, markets, and the natural, social, and economic environments (Hu and $\mathrm{Li}, 2013$ ). It promotes the co-evolution of innovation groups and innovation environment by connecting and transmitting material flow, energy flow, and information flow (Li, et al., 2014). It is more dynamic and evolutionary than innovation system.

Adner and Kapoor (2016) noted that technology substitution is not merely the competition between two technologies. It is also the competition between two technology ecosystems. Components and complements bring challenges to the emergence of new technology ecosystem. They also provide opportunities for extending old technology ecosystems. When a technology is seen as part of a system, the value that the technology can bring to its users depends on the technology itself as well as the 
interaction between the technology and other system elements, including technological elements and social-economic factors (Adner and Kapoor, 2016).

\subsection{Technological Trajectory Transition}

Existing literature has not clearly defined technological trajectory transition. Most literature focuses on the benefits generated by trajectory transformation and technology leapfrogging. Some scholars describe the technology leapfrogging process with two S-curves, which represent two technological development trajectories. The intersection of the two S-curves can be seen as the transition point or jump point, where one technological trajectory leapfrogs to the other and technological breakthrough generates technological discontinuous development (Olin and Shani, 2003). This paper defines technological trajectory transition as a process that breaks the path dependence of technological progress, such as leapfrogging some phases of technological development, or turning to a wholly different technological development path, to realize a different problem-solving pattern.

Dosi (1982) pointed out that technological trajectory evolution is built on the supplement and correlation among technology groups, not isolated individual development. Schumpeter (1982) noted that evolution is a process of creating new combination. When encountering technical problems, some firms search new knowledge and external technologies to offset the insufficiency of their existing knowledge and technologies. The new knowledge will supplement and extend their existing technologies instead of destroying them (Andersen, 1998; Bergek et al., 2013; Patel and Pavitt, 1994; Pavitt, 1986; Monticolo et al 2020; Xu, Wang, Luo and Shi 2006). Their existing technologies still work or even dominate after new technologies emerge.

CCT is the process of searching capabilities and technologies outside firms to supplement and extend their existing capabilities and technologies and then realize a different problem-solving pattern. Figure 1 shows the path of CAT.

In a CCT, technological trajectory does not change fundamentally. Instead, existing technological path can be optimized by combining new technologies and the existing technologies. The path optimization improves product performance. Usually, new technologies offset the performance insufficiency of existing technologies in two manners. The first manner is that new technologies are utilized as an add-on to the existing technologies for improving product performance. The second manner is to reconfigure technological framework for realizing a wholly different function with a new configuration.

Some scholars argue that the transition of technological paradigms is a creative disruptive fundamental alteration (Christensen and Rosenbloom, 1995; Dosi, 1982). They noted that existing technological development trajectory would be disrupted by the new paradigm and leap to a new technological trajectory, as the leapfrogging from one continuous S-curve to another continuous S-curve shown in Figure 2 (Olin and Shani, 2003). CDT is a complete substitution of existing technologies by new technologies to achieve a fundamental alteration of problem-solving method.

The new paradigm, implying the discontinuity of technology development, tends to redefine the significance of technological progress, points out new technological problem categories and guides different technological development directions. In CDT, existing technologies are substituted completely by new ones to realize a different problem-solving method. It destroys firms' existing abilities, develops new abilities in new directions, and results in new product development.

Figure 2 illustrates a typical discontinuous development of technological trajectory induced by new technological paradigms. A new technology's performance is usually inferior to that of an existing technology in the initial stage. However, the new technology develop rapidly whereas the existing technology slow down its development. At Point Q in Figure 2, the performance of the new technology exceeds that of the existing technology. The existing technology is substituted by the new technology (Foster, 1986). Firms choose the new technology due to its superior performance. 
Figure 1. The path of CCT

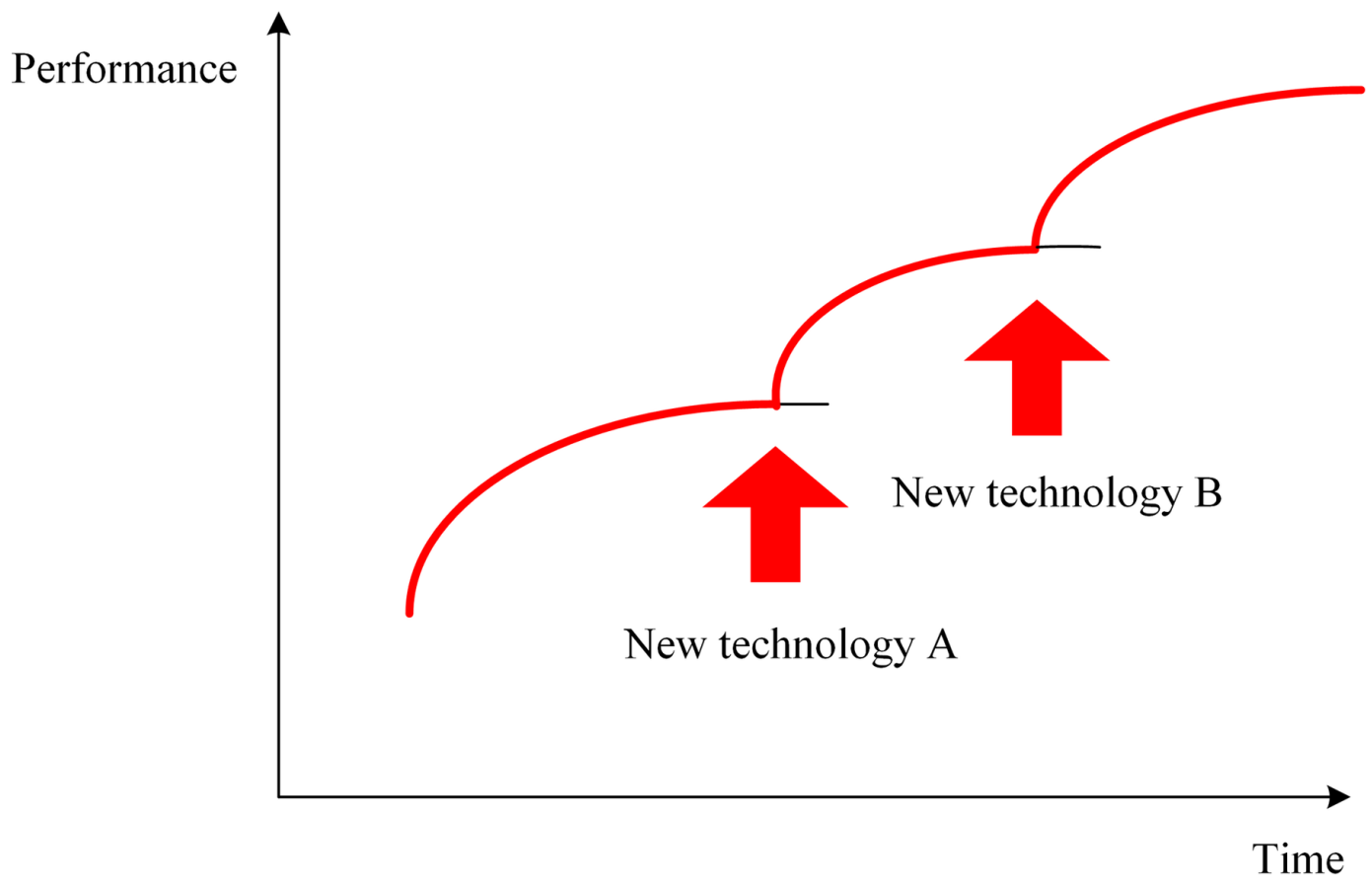

Figure 2. The path of CDT

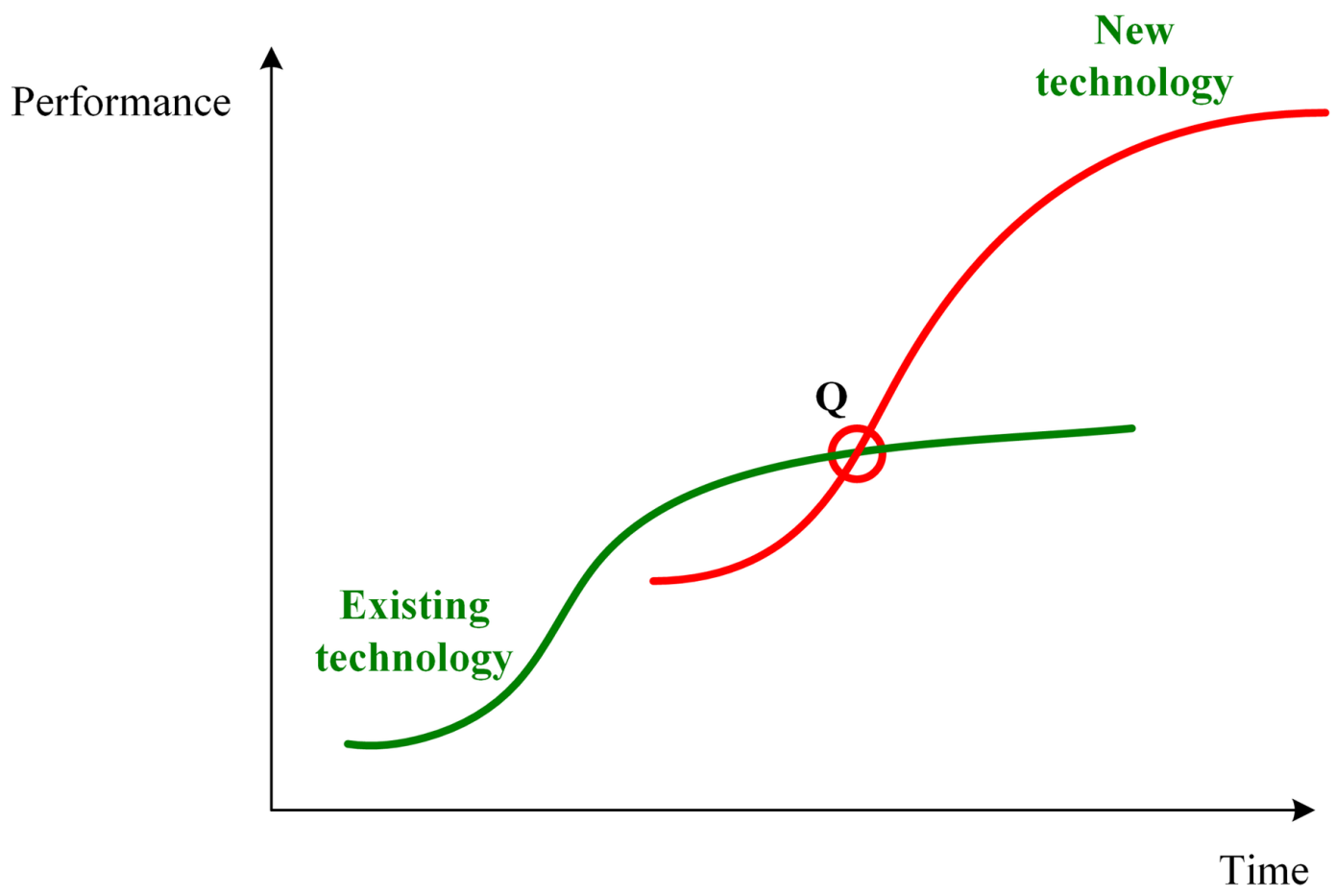




\section{HYPOTHESES DEVELOPMENT}

\subsection{Innovation Ecosystem and Technological Trajectory Transition}

Jerez-Gomez, Cespedes-Lorente, and Valle-Cabrera (2005) define organizational learning ability (LEA) as an organization's ability of processing knowledge, including the abilities of creating, acquiring, transferring and integrating knowledge, and adjusting organizational activities according to new cognitional conditions. In this paper, we define organizational learning ability as the capability of processing knowledge, including knowledge creation, acquisition, transmission and integration, as well as organization behavior adjust in align to new cognitive conditions. It has four dimensions: managerial commitments, systemic perspective, openness and experimentation, knowledge transmission and integration (Nwankpa \& Roumani, 2014; Jerez-Gomez, Cespedes-Lorente, \& Valle-Cabrera, 2005).

Managerial commitments refers to the ability of creating knowledge and supports and commitments from leaders (Akgun et al., 2007). Top managers play a vital role in establishing a learning atmosphere (Nwankpa \& Roumani, 2014). Effective management promotes knowledge acquirement, creation and transmission and establishes an open atmosphere and cultural diversities to receive new opinions and ideas (Jerez-Gomez, et al., 2005). Moreover, effective management promotes reform and makes firms ready for new challenges (Lei et al., 1999). Consequently, strong managerial commitments creates favorable conditions for technological trajectory transition through reforming organizational structure and culture. Systems perspective implies that organization members are aware of organizational goals and they know how to realize these goals (Lei et al., 1999; Xu 2013, 2020). Organizational members' understanding of their roles in an organization affect technological trajectory transition. Openness and experimentation refer to the extent to which an organization accepts new ideas, such as creating an organization structure encouraging new ideas and innovations (Nwankpa and Roumani, 2014). An open attitude to new ideas helps organization members to renew, extend, and continuously improve their knowledge (Leonard-Barton, 1992). It is beneficial for firms to develop radical innovations. Knowledge transmission refers to the transmission of knowledge in an organization through various channels (Jerez-Gómez, et al., 2005). The ability of overcoming the barriers between departments and transmitting new knowledge is vital for an organization to success (Nwankpa and Roumani, 2014). Given the role of organizational learning ability in firms' technological trajectory transition, we premise:

H1: Firms' organizational learning ability positively affects their CCT.

H2: Firms' organizational learning ability positively affects their CDT.

Network relationship strength (NET) refers to the strength of relationship among different actors. When innovation paradigm evolves from closed innovation, to open innovation, and then to network innovation (Salmelin, 2013), the effect of network on technological innovation becomes prominent. Traditional closed innovation can hardly meet firms' requirements for technological innovation. Thus, firms search external resources to achieve better innovation performance. The search makes network one vital factor in innovation ecosystem and innovative economy development (Hwang and Mabogunje, 2013). The transition of technological trajectory requires broader technological abilities that are needed by existing market (Pavitt, 1986) as well as alliances (Windrum, 2004).

In terms of the effect of network relationship strength(NET) on knowledge types and quality acquired by firms, some scholars argue that strong network is helpful for acquiring proprietary, complicated, and redundant knowledge, whereas weak network is helpful for acquiring novel and heterogeneous knowledge (Rogers,2003; Rowley et al.,2000;). Firms do not need to invest much time on sustaining relations in weak network ties. They possess more relation nodes and search knowledge and abilities broadly (Rogers, 2003). Moreover, in a weak network firms encounter fewer constrains from suppliers or other organizations. This leads to a lower cost of technology transformation and 
contributes to integrating or substituting new technologies and existing technologies. Consequently, weak network is in favor of firms' CCT and CDT. Hence, we premise:

H3: Firms' network relationship strength negatively affects their CCT.

H4: Firms' network relationship strength negatively affects their CDT.

Environmental concern (EC) is an estimate or attitude towards the effect of self or others' behaviors on environment (Takala, 1991). The subjects of environmental concern involve governments, firms' managers, stakeholders, and other institutions. In this study, we discuss governments' environmental concern (ENVG) and firms' environmental concern (ENVE).

Governments' environmental concern embodies environmental regulations (Fan 2017). Eiadat et al. (2008) defined environmental regulations as a series of environment policies that aim to reduce firms' influences on natural environment and to create favorable conditions for firms to engage in environmental innovations. Environmental regulation overcomes organizational inertia, accepts new ideas, encourages creative thoughts, and promotes technological progress (Porter, 1991; Porter and Van Der Linde, 1995). Environmental regulation promotes firms to engage in environmental innovation (Kemp, 1997). For example, California's Zero-Emission Vehicles policy issued in 1990(Sperling and Gordon,2009) promoted the development of fuel cell technology, positively affecting the technological trajectory transition of automobile industry from traditional internal combustion engine technology to fuel cell technology.

Schaefer (2004) pointed out that environment department managers promote the integration of social and environmental problems, making it as part of sustainable development. Eiadat et al. (2008) noted that managers, who positively concern environment, effectively promote firms to adopt environmental innovation strategy, and then promote technological trajectory turn to environmentfriendly path. In emerging economies, governments dominate resources and implement intervention activities on economy. Therefore, we premise:

H5: Governments' environmental concern positively affects firms' CCT.

H6: Governments' environmental concern positively affects firms' CDT.

H7: Firms' environmental concern positively affects their CCT.

H8: Firms' environmental concern positively affects their CDT.

\subsection{Innovation Ecosystem and Innovation Performance}

Innovation performance (PER) has been defined from diverse perspectives by scholars (Kumar \& Chanda 2018; Lei, Liu, Qi, and Zhang 2019; Sharma and Chanda 2017). For instance, Utterback and Abernathy (1975) defined that innovation performance consists of product innovation and process innovation. The former focuses on market and aims at customers, while the latter focuses on firms' internal processes and aims at improving efficiency. Hagedoorn and Cloot (2003) distinguished the narrowly defined innovation performance and the generalized one. The narrowly defined innovation performance refers to the commercialization degree of firms' technology inventions. The generalized innovation performance is related to patents, technical improvements, and innovation outcomes. Existing studies mainly measure innovation performance from the perspectives of efficiency and effectiveness. Innovation performance in this paper refers to the outputs, effect, and speed of innovations. Innovation outputs and effect embody effectiveness dimension, including patents, new products, sales growth, investment returns, competitive advantages, and customer satisfaction. Innovation speed embodies efficiency dimension, including new product development and launch speed.

Due to the fast changes of markets and technologies as well as the importance of information diversity and pre-action, firms' organizational learning ability is vital for their competitiveness (Santos 
et al., 2005). Firms with strong organizational learning ability can quickly grab new opportunities in market and allocate resources (Slater and Narver, 1995), and then launch new products quicker. Firms' organizational learning ability also help them to develop product innovation and process innovation (Amara, et al., 2008; Hsu and Fang, 2009). Moreover, firms' organizational learning ability plays a vital role between organic organization structure and performance. Consequently, we premise:

H9: Firms' organizational learning ability positively affects their innovation performance.

Network cooperation is found to positively affect firms' innovation performance (Beckett and Vachhrajani 2017; Chen and Xie 2018; Nieto and Santamaría, 2007; Zhang, Yang, Qi, Lei 2018). R\&D and network are considered as complementary drivers for innovation outputs. Inter-firm cooperation, including formal long-term strategic alliance and informal cooperation, lead to incremental innovation and radical innovation (Sammarra and Biggiero, 2008). Nieto and Santamaría (2007) found that heterogeneous network positively affects innovation novelty. They noted that cooperation with suppliers helps firms to develop and improve products, and then increases their sales. In addition, cooperation with users is favor of the development of new products and innovation with greater novelty (Fritsch and Lukas, 2001; Kaminski et al., 2008; Tether, 2002). Thus, firms cooperate more frequently with users when they desire innovation with greater novelty (Amara and Landry, 2005). Moreover, cooperation with colleges or research institutions is an important way to acquire new knowledges for small and medium-sized enterprises in developing countries (Li, Asunka et al 2020; Liefner et al., 2006; Yang, Chen, Zhang, Lei 2018). Zeng et al. (2010) found that cooperation networks, including inter-firm cooperation, cooperation with intermediaries and research institutes, positively affects the innovation performance of small and medium-sized enterprises. We therefore premise

H10: Firms' network relationship strength positively affects their innovation performance.

Environmental regulations trigger innovation and therefore enhance firms' performance (Porter, 1991). In addition, managers' concerns of environment are the most important determinants in firms' environmental innovation strategy, which positively affects firms' sales (Eiadat et al., 2008). Firms tend to innovate when managers concern natural environment. Thus, we premise

H11: Governments' environment concern positively affects firms' innovation performance.

H12: Firms' environment concern positively affects their innovation performance.

\subsection{Technological Trajectory Transition and Innovation Performance}

Existing technologies improve firms' performance by accelerating innovation speed and expanding innovation scope when facing threats from new technologies (Bergek et al., 2013). As a result, new knowledge and innovation outputs, such as intellectual property rights and new products, are developed by firms (Katila and Ahuja, 2002). On the other hand, accumulation formulates entry barriers and weakens new technologies' advantages (Bergek et al., 2013). Integrating with new technologies based on existing technological trajectory, incumbents can formulate a new trajectory and quickly improve product performance. We therefore premise

H13: Firms' CCT positively affects their innovation performance.

Creative destruction generates determined cost or quality advantages (Schumpeter, 1942). In creative disruptive technological trajectory transition, the probability of replacement increases when the performance of new technologies surpasses that of existing technologies. The existing paradigm 
constrains the boundary of existing technological trajectory, whereas the new paradigm provides new technologies, making various technological and economic trade patterns possible. Consequently, the new technological trajectory must prominently differ from the existing one (Dosi, 1988). Its advantages include high efficiency, low emission, and low cost (Rennings et al., 2013). Moreover, Figure 2 indicates that when CDT happens, the slope of new technological trajectory usually exceeds that of the existing technological trajectory, representing a faster performance improvement of new technologies and therefore generating more knowledge. Consequently, we premise

H14: Firms' CDT positively affects their innovation performance.

Figure 3 shows the research model that describes technological trajectory transition in innovation ecosystem and their relations with innovation performance.

Figure 3. The research model

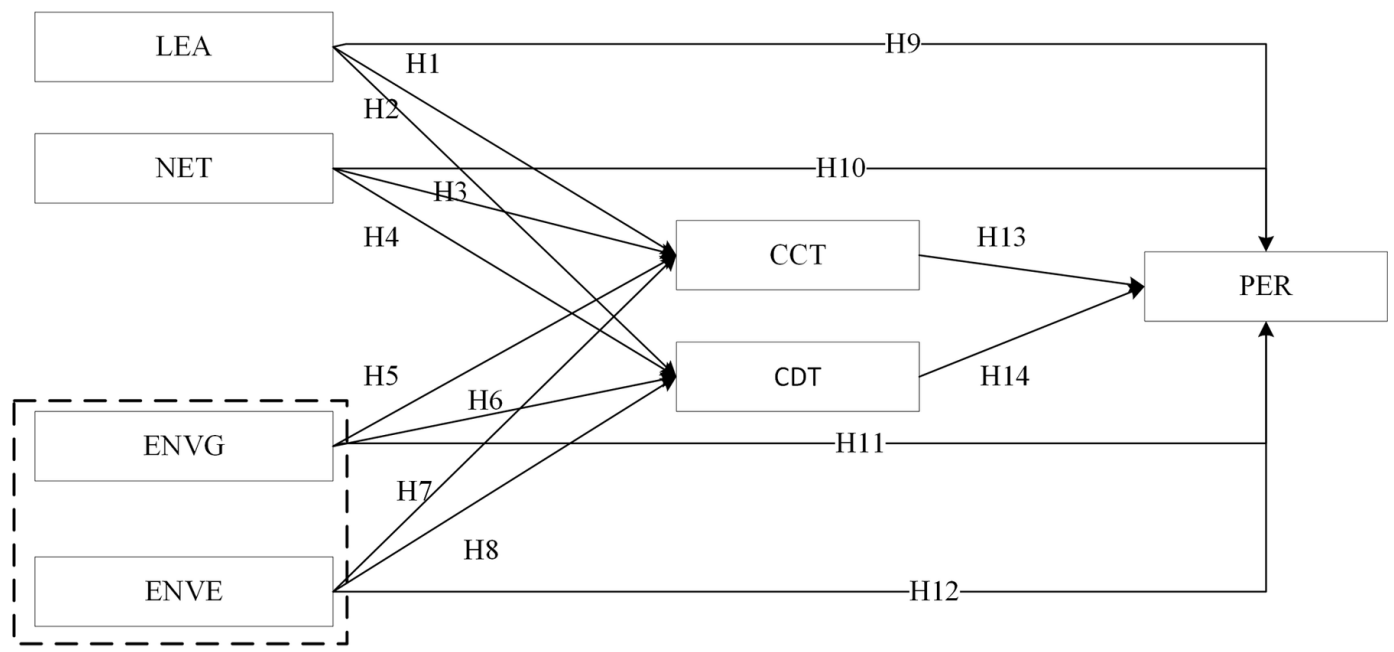

\section{RESEARCH METHOD}

\subsection{Measurements}

Based on the model in in Jerez-Gómez et al. (2005), this paper chooses four items to measure firms' organization learning ability. In specific, LEA1 checks whether firms' learning ability is seen as a vital factor. LEA2 checks whether each element in firms (departments, sections, teams, and individuals) is aware of how they contribute to realize their goals. LEA3 checks whether firms improve their processes through experimentation and innovation. LEA4 checks whether firms have tools (documents, database, and processes) to accumulate knowledge so that the mobilization does not generate much influences.

Granovetter(1977) measured network relationship strength with four dimensions: amount of time, emotional intensity, intimacy, and reciprocal. Similarly, Pan and Cai (2010) measured network relationship strength with four dimensions: amount of time, inputs, scope of cooperation, and reciprocal. Based on these two models, this paper measures network relationship strength with four dimensions. NET1 checks whether communication with innovation partners occur frequently and last for a long time. NET2 checks whether cooperation with innovation partners is comprehensive. NET3 
checks whether information sharing with innovation partners is complete. NET4 checks whether cooperation with innovation partners is a win-win relationship.

Existing literatures have measured environmental concern from various dimensions (Chen, Yao, and Chong 2019). For example, Xiao and Dunlap (2007) developed a comprehensive scale to measure public environmental concern. Eiadat et al. (2008) examined how government environmental regulation, pressures from stakeholders and managers' attitude towards environmental innovation affect firms' environmental innovation strategy. This paper measures environmental concern from two perspectives: government environmental regulation and managers' attitude towards environmental innovation. In specific, this paper applies four items to measure government environmental regulation (ENVG). ENVG 1 checks whether environmental regulations are strict for firms. ENVG 2 checks whether environmental regulations fit to the areas that the firms locate. ENVG 3 checks whether environmental regulations are clear. ENVG 4 checks whether environmental regulations effectively resolve environmental problems. Meanwhile, we adopt four items to measure firms' environmental concern (ENVE). ENVE 1 checks whether the development of environmental technologies is necessary for firms. ENVE 2 checks whether the development of environmental technologies is an important part of firms' strategy. ENVE 3 checks whether most environmental technologies developments are worthy. ENVE 4 checks whether the development of environmental technologies is an effective strategy.

We measure CCT with five dimensions: technology, ability, process, and product. Here are the details of the measurements. CCT 1 checks whether firms will abandon their existing technologies when facing challenges from new technologies. CCT 2 checks whether firms will utilize new technologies to supplement and extend their existing technologies when they do not meet market requirements. CCT 3 checks whether firms will search new abilities outside their existing knowledge base to extend their existing abilities. CCT 4 checks whether firms will integrate their existing technologies with new technologies to acquire a different problem-solving method. CCT 5 checks whether firms will integrate their existing technologies with new technologies to improve performance of their products.

We measure CDT with five dimensions as well: technology, ability, process, and product. CDT 1 checks whether firms will substitute the existing technology with a new technology when it emerges. CDT 2 checks whether firms will shift to a new technology when an existing one does not meet users' needs. CDT 3 checks whether firms will destroy their existing abilities and develop new abilities in new technological directions. CDT 4 checks whether firms will substitute an existing technology with a new one to achieve a complete transformation of problem-solving method. CDT 5 checks whether firms will substitute an existing technology with a new one to provide new products.

Hagedoorn and Cloodt (2003) measured innovation performance with four dimensions: investment on R\&D, patent applications, patent citations, and new product development. Alegre and Chiva (2013) chose product innovation effectiveness, process innovation effectiveness and innovation efficiency, and developed 21 items to measure innovation performance. Qian et al. (2010) selected new products/ services and new technology application. Xie and Xu (2014) developed six measurements in two dimensions to examine new products and patents. Yuan et al. (2015) developed 12 measurements in two dimensions to gauge process performance and result performance. Based on these studies, we develop five items to measure innovation performance. PER 1 checks whether firms usually launch new products or services earlier than competitors. PER 2 checks whether firms' products have more high-technologies than competitors' products. PER 3 checks whether the market responses of new products are better than that of competitors. PER 4 checks whether the development speed of products is faster than that of competitors. PER 5 checks whether the Input-output rate of new products is higher than that of competitors.

\subsection{Sample and Data}

This study developed a questionnaire and conducted a survey to test the hypotheses. The questionnaire contains two parts. Part 1 collects basic information of firms. Part 2 contains questions for measuring 
the six constructs with 5-point Likert-type scales ranging from $1=$ strongly disagree to $5=$ strongly agree.

Questionnaires were sent to R\&D managers or directors of technology center of firms in industrial parks in five provinces in China, including Liaoning, Jilin, Shandong, Zhejiang, and Guangdong. The survey began in May 2008 and stopped in June 2008. Altogether, we received 412 responses, of which 366 (or $88.8 \%$ ) were valid.

The annual sales of the firms in the survey ranged from less than 60 million RMB to more than 10 billion RMB. Forty-six of the firms have been established for 1-3 years (12.6\% of the whole sample). Ninety six have been established for 3-5 years (26.2\%). One hundred and twenty three have been established for 5-10 years (33.6\%). One hundred and one have been established more than 10 years $(27.6 \%)$. One hundred and five firms are in the industry of information transformation, computer service and software (28.7\%). Ninety-five firms are in the industry of vehicle and parts manufacturing (26\%). Sixty-nine firms are in chemical industry (18.9\%). Thirty-six firms are in the industry of electrical machinery $(9.8 \%)$. Sixty-one firms are in transportation, warehousing and post industry $(16.7 \%)$.

\section{EMPIRICAL RESULTS}

We applied SPSS to analyze the relevance of all the variables. Table 1 shows the results of correlation analysis, which indicate that all variables are correlated with each other.

Table 2 shows the Cronbach's alpha values for each variable. Cronbach's alpha for firms' environmental concern is 0.782 , while Cronbach's alpha is 0.879 when the first item is removed. Consequently, we eliminate the first item in the measurements for firms' environmental concern.

Most constructs and items in the research model are adopted from the existing literature. Some are revised according to suggestions acquired from senior managers and experts. Thus, content validity of the constructs is well established. Moreover, the results of factor analysis indicated construct validity for each variable.

We applied LISREL to estimate each path coefficient of the conceptual model and calculated their T-values. The results are shown in Figure 4. They indicated that all path coefficients are significant at the 0.01 level. The values of CFI, NFI, NNFI, IFI, GFI, PNFI and RFI are close to 0.90 . Therefore, the overall fit of the model is satisfactory.

Of the 14 hypotheses tested, ten are supported and four are rejected. The details are listed in Table 3.

H1 to H8 examines the impacts of firms' organizational learning ability, network relationship strength, and governments' environmental concern on the two patterns of technological trajectory transition. The results indicate that firms' organizational learning ability, network relationship strength, and governments' environmental concern positively affect the two patterns of technological trajectory transition. The impact from firms' organizational learning ability is largest.

The supports of $\mathrm{H} 1$ and $\mathrm{H} 2$ indicate that firms' organizational learning ability positively affects their CCT and CDT. The positive effects of firms' organizational learning ability involve three aspects. Firstly, firms' organizational learning ability promote knowledge acquisition. It creates and transmits firms' basic values, enabling them to adopt new ideas, assimilate, and transfer external knowledge and technologies. Such ability also help firms to generate new knowledge. Secondly, firms' organizational learning ability helps them to establish an open attitude towards new ideas. This attitude enables firms to search new knowledge and technologies for supplementing and extending their existing abilities. Moreover, firms' open attitude towards new ideas enables employees to constantly learn new knowledge, so that employees' knowledge can be continuously renewed. New 
Table 1. Results of correlation analysis

\begin{tabular}{|c|c|c|c|c|c|c|c|c|}
\hline & & LEA & NET & ENVG & ENVE & CCT & CDT & PER \\
\hline \multirow{3}{*}{ LEA } & Pearson & 1.000 & 0.578 & 0.421 & 0.361 & 0.628 & 0.561 & 0.570 \\
\hline & Significance & & 0.000 & 0.000 & 0.000 & 0.000 & 0.000 & 0.000 \\
\hline & $\mathrm{N}$ & 366 & 366 & 366 & 366 & 366 & 366 & 366 \\
\hline \multirow{3}{*}{ NET } & Pearson & 0.578 & 1.000 & 0.371 & 0.183 & 0.460 & 0.529 & 0.585 \\
\hline & Significance & 0.000 & & 0.000 & 0.000 & 0.000 & 0.000 & 0.000 \\
\hline & $\mathrm{N}$ & 366 & 366 & 366 & 366 & 366 & 366 & 366 \\
\hline \multirow{3}{*}{ ENVG } & Pearson & 0.421 & 0.371 & 1.000 & 0.406 & 0.596 & 0.509 & 0.319 \\
\hline & Significance & 0.000 & 0.000 & & 0.000 & 0.000 & 0.000 & 0.000 \\
\hline & $\mathrm{N}$ & 366 & 366 & 366 & 366 & 366 & 366 & 366 \\
\hline \multirow{3}{*}{ ENVE } & Pearson & 0.361 & 0.183 & 0.406 & 1.000 & 0.464 & 0.298 & 0.082 \\
\hline & Significance & 0.000 & 0.000 & 0.000 & & 0.000 & 0.000 & 0.103 \\
\hline & $\mathrm{N}$ & 366 & 366 & 366 & 366 & 366 & 366 & 366 \\
\hline \multirow{3}{*}{$\mathrm{CCT}$} & Pearson & 0.628 & 0.460 & 0.596 & 0.464 & 1.000 & 0.597 & 0.448 \\
\hline & Significance & 0.000 & 0.000 & 0.000 & 0.000 & & 0.000 & 0.000 \\
\hline & $\mathrm{N}$ & 366 & 366 & 366 & 366 & 366 & 366 & 366 \\
\hline \multirow{3}{*}{ CDT } & Pearson & 0.561 & 0.529 & 0.509 & 0.298 & 0.597 & 1.000 & 0.587 \\
\hline & Significance & 0.000 & 0.000 & 0.000 & 0.000 & 0.000 & & 0.000 \\
\hline & $\mathrm{N}$ & 366 & 366 & 366 & 366 & 366 & 366 & 366 \\
\hline \multirow{3}{*}{ PER } & Pearson & 0.570 & 0.585 & 0.319 & 0.082 & 0.448 & 0.587 & 1.000 \\
\hline & Significance & 0.000 & 0.000 & 0.000 & 0.103 & 0.000 & 0.000 & \\
\hline & $\mathrm{N}$ & 366 & 366 & 366 & 366 & 366 & 366 & 366 \\
\hline
\end{tabular}

knowledge acquired by employees is beneficial for the development of radical innovation. Lastly, firms' organizational learning ability helps them to overcome the barriers between departments and to promote the transmission of new knowledge across the firms oriented by processes. Smooth transmission of new knowledge is beneficial for the success of innovation.

The supports of H3 and H4 indicate that firms' network relationship strength negatively affects their CCT and CDT. Maintaining a strong relation with external network requires firms to invest a large amount of time and energy. This causes firms to rely more on the network and invest more on technology transforming. Moreover, strong network relationship narrows firms' searching scope. This hinders firms from acquiring more novel and heterogeneous knowledge.

The supports of H5 and H6 indicate that governments' environmental concerns positively affect firms' CCT and CDT. The result is consistent with the findings in Porter (1991) and Porter and Van Der Linde (1995). Governments' environmental regulations overcome organizational inertia, enable firms to accept new ideas and new technologies, encourage creative thinking, and promote technological progress. Governments' environmental regulations consist of a series of environmental laws and regulations, technical standards, and industrial policies. Governments can constrain the firms that negatively affect natural environment by implementing laws and regulations. These firms have to upgrade their manufacturing technologies (CCT) or adopt new technologies and manufacturing processes (CDT) to meet the requirements set by laws and regulations. In addition, technical standard is an approach for enforcing environmental regulations. Governments can set limitations on those firms 
Table 2. Results of reliability test

\begin{tabular}{|c|c|c|c|}
\hline Constructs & Items & Cronbach's $\alpha$ after eliminating & Cronbach's $\alpha$ \\
\hline \multirow{4}{*}{$\begin{array}{l}\text { Organizational learning ability } \\
\text { (LEA) }\end{array}$} & LEA1 & 0.743 & \multirow[t]{4}{*}{0.758} \\
\hline & LEA2 & 0.657 & \\
\hline & LEA3 & 0.678 & \\
\hline & LEA4 & 0.722 & \\
\hline \multirow{4}{*}{$\begin{array}{l}\text { Network relationship strength } \\
\text { (NET) }\end{array}$} & NET1 & 0.707 & \multirow[t]{4}{*}{0.780} \\
\hline & NET2 & 0.696 & \\
\hline & NET3 & 0.748 & \\
\hline & NET4 & 0.754 & \\
\hline \multirow{4}{*}{$\begin{array}{l}\text { Governments' environmental concern } \\
\text { (ENVG) }\end{array}$} & ENVG1 & 0.824 & \multirow[t]{4}{*}{0.852} \\
\hline & ENVG2 & 0.790 & \\
\hline & ENVG3 & 0.789 & \\
\hline & ENVG4 & 0.840 & \\
\hline \multirow{4}{*}{$\begin{array}{l}\text { Firms'environmental concern } \\
\text { (ENVE) }\end{array}$} & ENVE1 & 0.879 & \multirow[t]{4}{*}{0.782} \\
\hline & ENVE2 & 0.689 & \\
\hline & ENVE3 & 0.655 & \\
\hline & ENVE4 & 0.658 & \\
\hline \multirow[t]{5}{*}{$\mathrm{CCT}$} & CUM1 & 0.868 & \multirow[t]{5}{*}{0.852} \\
\hline & CUM2 & 0.819 & \\
\hline & CUM3 & 0.814 & \\
\hline & CUM4 & 0.810 & \\
\hline & CUM5 & 0.793 & \\
\hline \multirow[t]{5}{*}{ CDT } & DES1 & 0.815 & \multirow[t]{5}{*}{0.840} \\
\hline & DES2 & 0.818 & \\
\hline & DES3 & 0.825 & \\
\hline & DES4 & 0.784 & \\
\hline & DES5 & 0.796 & \\
\hline \multirow{5}{*}{$\begin{array}{l}\text { Innovation performance } \\
\text { (PER) }\end{array}$} & PER1 & 0.866 & \multirow[t]{5}{*}{0.902} \\
\hline & PER2 & 0.893 & \\
\hline & PER3 & 0.878 & \\
\hline & PER4 & 0.877 & \\
\hline & PER5 & 0.885 & \\
\hline Aggregate table & - & - & 0.931 \\
\hline
\end{tabular}


Figure 4. Results of testing the structural equation model

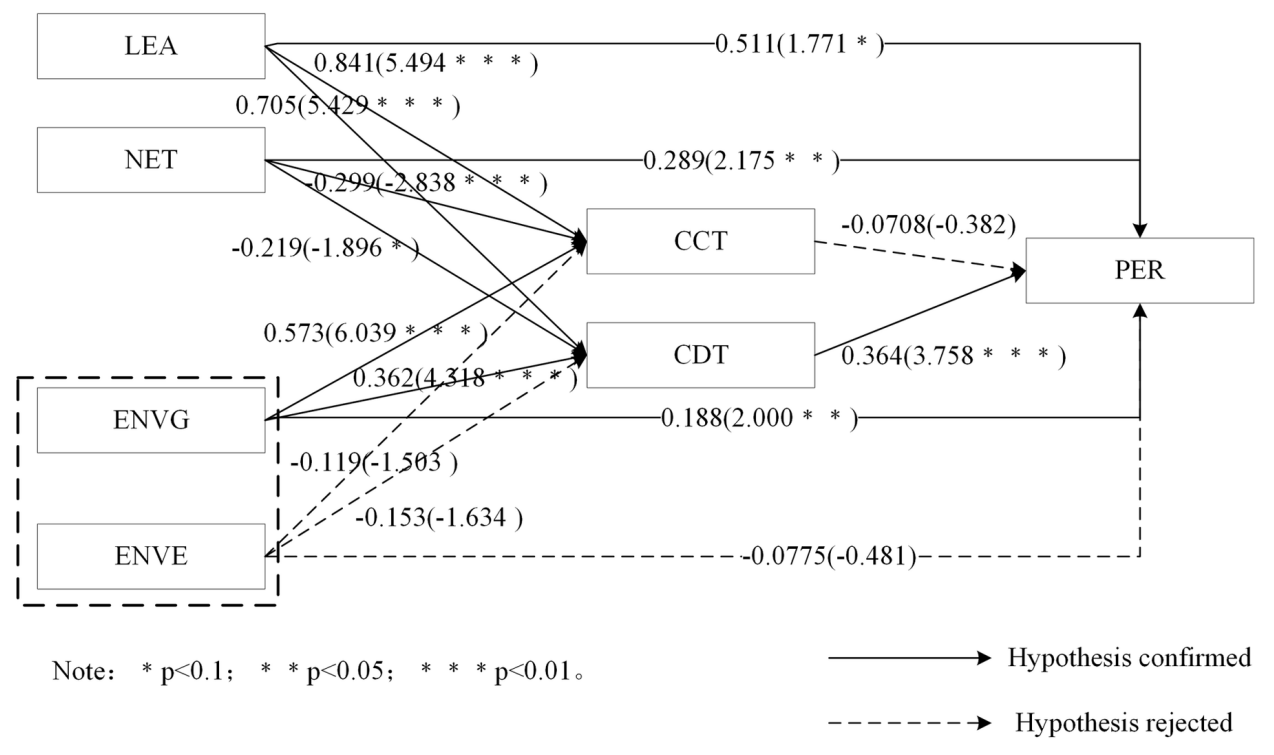

Table 3. Results of hypotheses test

\begin{tabular}{|c|c|c|}
\hline Relationship & Hypotheses & Result \\
\hline \multirow[t]{8}{*}{$\begin{array}{l}\text { Innovation ecosystem and } \\
\text { technological trajectory transition }\end{array}$} & $\begin{array}{l}\text { H1: Firms' organizational learning ability positively affects } \\
\text { their CCT. }\end{array}$ & Supported \\
\hline & $\begin{array}{l}\text { H2: Firms' organizational learning ability positively affects } \\
\text { their CDT. }\end{array}$ & Supported \\
\hline & $\begin{array}{l}\text { H3: Firms' network relationship strength negatively affects their } \\
\text { CCT. }\end{array}$ & Supported \\
\hline & $\begin{array}{l}\text { H4: Firms' network relationship strength negatively affects their } \\
\text { CDT. }\end{array}$ & Supported \\
\hline & $\begin{array}{l}\text { H5: Governments' environmental concern positively affects } \\
\text { firms' CCT. }\end{array}$ & Supported \\
\hline & $\begin{array}{l}\text { H6: Governments' environmental concern positively affects } \\
\text { firms' CDT. }\end{array}$ & Supported \\
\hline & H7: Firms' environmental concern positively affects their CCT. & Rejected \\
\hline & H8: Firms' environmental concern positively affects their CDT. & Rejected \\
\hline \multirow[t]{4}{*}{$\begin{array}{l}\text { Innovation ecosystem and } \\
\text { innovation performance }\end{array}$} & $\begin{array}{l}\text { H9: Firms' organizational learning ability positively affects } \\
\text { their innovation performance. }\end{array}$ & Supported \\
\hline & $\begin{array}{c}\text { H10: Firms' network relationship strength positively affects } \\
\text { their innovation performance. }\end{array}$ & Supported \\
\hline & $\begin{array}{l}\text { H11: Governments' environment concern positively affects } \\
\text { firms' innovation performance. }\end{array}$ & Supported \\
\hline & $\begin{array}{l}\text { H12: Firms' environment concern positively affects their } \\
\text { innovation performance. }\end{array}$ & Rejected \\
\hline \multirow[t]{2}{*}{$\begin{array}{l}\text { Technological trajectory transition } \\
\text { and innovation performance }\end{array}$} & $\begin{array}{l}\text { H13: Firms' CCT positively affects their innovation } \\
\text { performance. }\end{array}$ & Rejected \\
\hline & $\begin{array}{l}\text { H14: Firms' CDT positively affects their innovation } \\
\text { performance. }\end{array}$ & Supported \\
\hline
\end{tabular}


with low technology level and high pollutions by implementing technical standards. Thus, these firms have to improve their existing technologies and induce new technologies. Moreover, governments can create favorable conditions for firms to engage in environmental innovation and technological trajectory transition by implementing supportive industrial policies.

The rejections of $\mathrm{H} 7$ and $\mathrm{H} 8$ indicate that firms' environmental concerns do not positively affect their CCT or CDT. This result is not consistent with the findings in Schaefer (2004) and Eiadat et al. (2008). Firm managers who concern environment tend to adopt environmental innovation strategy for resolving social and environmental problems. Their concerns drive firms to choose a sustainable technological trajectory. However, this study finds that managers in Chinese firms do not concern environment so much. As a result, Chinese firms' technological trajectory transition is not affected by their managers' environmental concern. Due to the lack of supervision, the imperfect of market mechanism, and the failure of negative externality internalizing into firms' costs, the costs for polluting environment are not high whereas the costs for reducing pollution are high. This implies that Chinese firms lack social responsibility. Moreover, firm managers do not pay much attention to sustainable development. They lack the abilities of strategic thinking. Thus, sustainable development is not a strategic choice for Chinese firms, which are not motivated for protecting environment and developing environmental technologies. Governments' environmental concern, not firms' environmental concern, is the driver of technological trajectory transition in China.

The support of $\mathrm{H} 9$ indicates that firms' organizational learning ability positively affects their innovation performance. The result is consistent with the findings in Mallén et al.(2016), Santos et al.(2005), and Slater and Narver (1995). Firms' organizational learning ability enable them to develop product or process innovation with their existing resources, generate more new knowledge through recognition, acquisition, absorption, and transformation of external resources, and then launch more new products to market and improve their innovation performance. Facing faster change of market needs and the need of customized production, successful firms need to acknowledge timely and meet users' diversified needs. Strong organizational learning ability enables firms to rapidly observe new market opportunities and allocate resources to meet market needs. Moreover, strong organizational learning ability enables firms to rapidly assimilate and transform new knowledge and technologies acquired externally, to improve their abilities, and to shorten product development cycle.

The support of H10 indicates a positive effect of firms' network relationship strength on their innovation performance. This result is consistent with the findings in Amara and Landry (2005), Nieto and Santamaría (2007), and Tether (2002). Firms sustain relationship with colleges, research institutes, suppliers, users, and government to acquire resources, to promote knowledge creation and innovation, and then to improve innovation performance. Establishing strong relationship with colleges and research institutes, especially for small and medium-sized firms, is helpful for acquiring new knowledge and technologies and developing new products. In addition, close cooperation with suppliers is beneficial for product development and improvement. Suppliers' early involvement in product development improve accuracy of product design, reduce design alteration, and hence reduce product development risks and shorten development cycle. Sustaining close relationship with users and timely acknowledge users' needs are beneficial for new product development. User participation in product innovation helps firms to create new products that meet market's needs. Moreover, maintaining good relationship with government is beneficial for firms to acquire legitimacy and support.

The support of H11 indicates a positive effect of governments' environmental concern on firms' innovation performance. This result is consistent with the finding in Porter (1991). Governments' environmental concern improves firms' performance through promoting them to innovate. When governments dominate resources and pose interventions on firms, governments' concern on environment allocates more resources to environmental technologies, formulate more environmental regulations, and promote the development of environmental technologies, driving firms to provide more new technologies and products. 
The rejection of H12 indicates that firms' environmental concern does not affect their innovation performance. This result is not consistent with the finding in Eiadat et al. (2008). Firm managers with environmental concern tend to adopt environmental innovation strategy to promote the development of environmental technologies, to reduce enterprise production damages on natural environment, and to develop green products and improve competitiveness. However, the data does not support this hypothesis. Environment concern involves developing environmental technologies and introducing environmental equipment. These activities increase costs and decrease input-output rate in short term. Most firms surveyed in this study are state-owned enterprises. Managers focus more on shortterm returns because they attempt to improve firm performance during the period when they are in office to strive for a higher position. In addition, environment is not on the list of their performance evaluation. Thus, even though environmental technologies can increase firms' competitiveness in the long run, managers focus on short term goals and neglect the positive impact of environmental investment on their firms' innovation performance.

The rejection of H13 indicates that CCT does not affect firms' innovation performance. This is not consistent with the finding in Bergek et al. (2013). Searching new knowledge and abilities to supplement and extend existing abilities enables firms to possess new knowledge and to generate innovative outputs, and then to improve their innovation performance. However, the data does not support this hypothesis. Firms surveyed in this study have weak technological ability and absorptive capacity. Technological ability is vital for allocating innovation resources and improving innovation efficiency. Firms with weak technological ability can hardly understand new technologies or integrate new technologies into their existing technologies to provide new products. Absorptive capacity refers to the ability of learning, transforming, and diffusing external knowledge. Firms with weak absorptive capacity can neither absorb or assimilate new technologies and abilities, nor supplement or extend their existing abilities. Furthermore, firms surveyed in this study lack technological accumulation. Creation and accumulation are two indispensable aspects of CCT. Technological accumulation reflects the knowledge and experience of firms. The lack of technological accumulation largely decrease firms' performance.

The support of H14 indicates a positive effect of CDT on innovation performance. Creative disruption generates large cost and quality advantages. The speed of technological performance improvement will gradually slow down along existing technological trajectory. Meanwhile, firms' competitive advantage will gradually decrease with latecomers' pouring in. The new technological trajectory provides advantages, such as high efficiency and low cost. Firms' shifting to new technologies and developing new abilities in new technological direction are beneficial for them to acquire competitive advantage in new technological trajectory. Early technology accumulation in the new trajectory helps firms to form entry-barrier, to take the lead in launching new products, and to generate higher performance.

Figure 5 summarizes the findings in this study.

\section{CONCLUSION}

This paper explores the mechanisms among innovation ecosystem (Achi et al 2016; Chen 2016; Hämäläinen and Inkinen 2019; Lu and Zheng 2020; Padmanathan et al 2018); Wipulanusat et al 2020), technological trajectory transition, and firms' innovation performance by developing a structural equation model. A questionnaire-based survey was conducted in China to collect data for examining the model. In specific, the impacts of three social economic factors in innovation ecosystems, namely firms' organizational learning ability, firms' network relationship strength, and environmental concern, on their technological trajectory transition and innovation performance are examined. Moreover, the impact of firms' technological trajectory transition on their innovation performance is examined as well. The following implications can be drawn from the results in this study for managers in their innovation decision-making processes. 


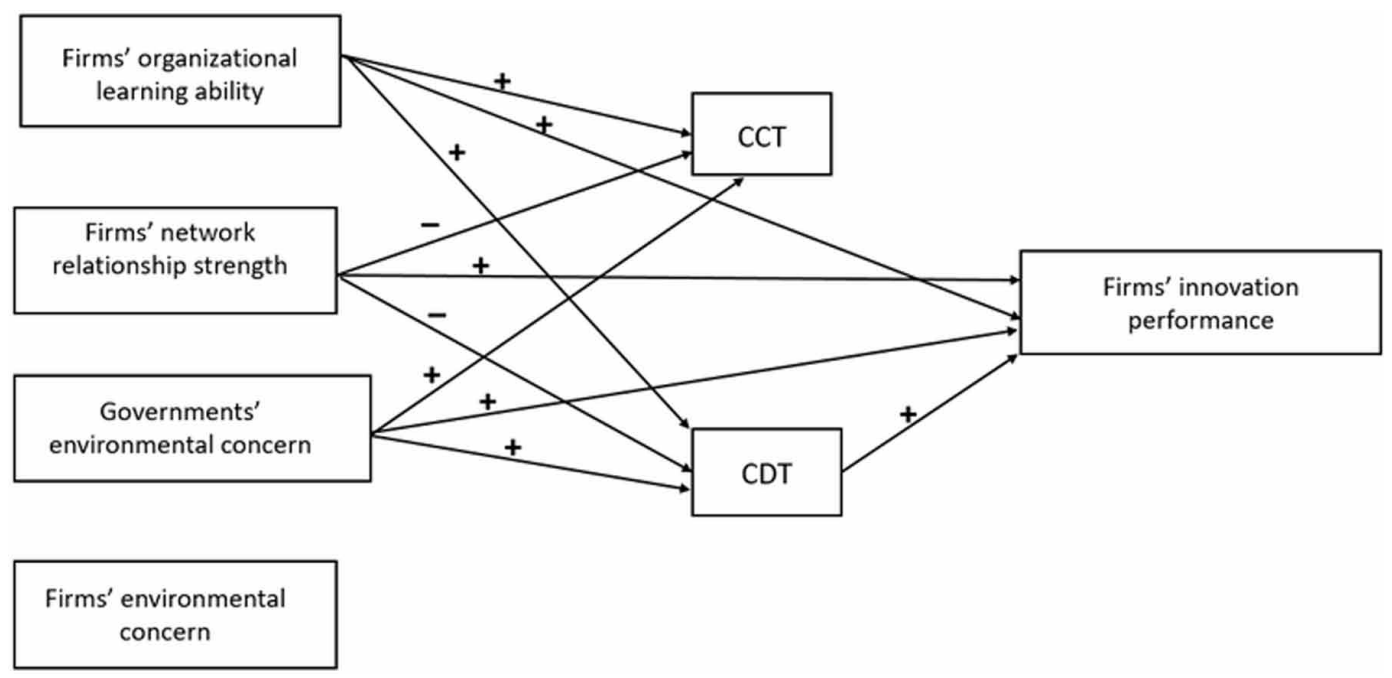

Firstly, we expect positive impacts of CCT and CDT on firms' innovation performance. However, the results indicate that CCT does not positively affects firms' innovation performance and that CDT positively affects firms' innovation performance. Therefore, firms should adopt CDT to achieve improvements in their innovation performance. Instead of incremental improvement along their existing technological trajectory, firms should replace their existing technology with emerging technologies, develop capabilities in new technological directions, and develop new products.

Secondly, the results in this study indicate that firms' organizational learning ability positively affects CCT, CDT, and firms' innovation performance. It is important for firms to improve their organizational learning ability from three perspectives.

1. Set clear organization strategic goals and formulate a complete goals system by decompose the goals into departments, sections, and individuals. Each component of the firm should formulate a plan in align with the strategic goals. The plan enables every unit in the firm acknowledges how to realize the organization strategic goals.

2. Promote knowledge accumulation (Feng and Xu 1996; Li 2020). Firms should transmit and accumulate important data by adopting integrated information systems (Fang et al 2017; Li and Xu 1991; Xu 2016), such as Enterprise Systems (Niu et al 2014; Xu 2011, 2014), Enterprise Information Systems (Gorkhali and Xu 2016, 2019; Li, Markowski, et al 2008; Niu et al 2013), Enterprise Resource Planning (Wang et al 2005; Wu et al 2009). By explicating tacit knowledge, process document is another essential method to accumulate knowledge. It allows new employees to learn how to perform their work quickly. Although process systems differ across firms, they mainly consists of three parts, namely rules and regulations, business processes (Gorkhali and Xu 2017; Tan et al 2010, 2013; Viriyasitavat, Xu, Viriyasitavat 2014; Wang et al 2007; Wang, Niu, Alenazi, Xu 2019; Xu et al 2008; 2014; Xu and Viriyasitavat 2014; Zhang et al 2011), and operation instructions. Firms should develop process framework using process method and integration thoughts, and then formulate complete process systems in align with their process frameworks.

3. Build learning organizations. A learning organization involves five elements, namely vision, leadership, experimentation, knowledge transmission, and teamwork. Vision refers to a clarified and recognized strategy. 
Thirdly, network relationship strength negatively affects CCT and CDT, but positively affects firms' innovation performance. This indicates that a close relationship with partners generates certain performance improvement. Network relationship in emerging economies is unique. Due to imperfect capital market, it is hard for firms to acquire resources in market. The cost of utilizing network to acquire resources is lower. Therefore, firms tend to utilize their network rather than market to acquire resources in entrepreneurship (Zhang and Wong, 2008). In addition, emerging economies are ethical standard. Bian (1997) noted that because strong relationship enhances the executive power and degree of trust of human relationship obligation, strong network ties usually cause the transmission of social information. Moreover, institution in transitional economy is imperfect (Park and Luo, 2001; Sheng, et al., 2011). Governments dominate resources in emerging economies (Sheng, et al., 2011). Thus, they implement intervention on firms (Park and Luo, 2001). Consequently, firms in emerging economies attempt to establish commercial relationships with other firms, suppliers, and users, and to sustain good relationship with governments for acquiring legitimacy and resources (Peng and Luo, 2000).

Fourth, governments' environmental concern positively affects CCT and CDT, whereas firms' environmental concern does not. Governments' environmental concern not only directly and positively affects firms' innovation performance, but also positively impacts firms' innovation performance through CDT. Firms' environmental concern neither directly and positively affects firms' innovation performance, nor affects firms' innovation performance through CCT or CDT.

In emerging economies (Lei, Zhang, Qi 2020; Li 2013, 2018; Li and Zhou 2013), governments dominate resources and implement intervention activities on economy. Moreover, due to the imperfect institutions, governments' environmental regulation positively affect firms' green innovation. Qi et al. (2010) noted that firms' managers play a vital role in green innovation practices. Liang et al. (2015) point out that governments should formulate environment policies to lead cleaner production mechanism and green product innovation. The results in this study indicate that government significantly affects firms' technological direction choice. Therefore, government should take full advantage of this superiority and lead firms to develop environmental technologies and reduce their impacts on environment through developing environmental rules and regulations, environmental technology standard or industrial policies.

This paper has several limitations. Because many new constructs are adopted in this study, the number of surveyed firms is limited and the results gained from the data need to be validated by future studies. Moreover, new constructs, such as CCT and CDT, are developed based on theoretical analysis and explorative case studies. More work is needed to refine and test them. Finally, the research model is built on generic theories. We link it with Chinese firms' technological innovation and catch-up processes. Future studies should validate the findings in this study using data from other emerging economies.

Despite the limitations, this paper provides a guidance for resolving the dilemmas inherent in the innovation practices when firms in emerging economies try to catch up the leaders. To improve the research model in this study, future studies should considering more socio-economic factors in the innovation ecosystem, such as institutions, organization structure, and corporate culture. In addition, future studies should explore the factors that affect the implement technological trajectory transition. Particularly, radical innovation maturity and firms' capability need to be examined.

\section{ACKNOWLEDGMENT}

This research is supported by the Zhejiang Provincial Natural Science Foundation of China (Grant LQ20G020013), National Natural Science Foundation of China (Grant 72072048) and Scientific Research Foundation of Hangzhou Dianzi University (Grant KYS395619083). 


\section{REFERENCES}

Achi, A., Salinesi, C., \& Viscusi, G. (2016). Innovation capacity and the role of information systems: A qualitative study. Journal of Management Analytics, 3(4), 333-360. doi:10.1080/23270012.2016.1239228

Adner, R., \& Kapoor, R. (2016). Innovation ecosystems and the pace of substitution: Re-examining technology S-curves. Strategic Management Journal, 37(4), 625-648. doi:10.1002/smj.2363

Akgün, A. E., Byrne, J. C., Lynn, G. S., \& Keskin, H. (2007). Organizational unlearning as changes in beliefs and routines in organizations. Journal of Organizational Change Management, 20(6), 794-812. doi: $10.1108 / 09534810710831028$

Alegre, J., \& Chiva, R. (2013). Linking entrepreneurial orientation and firm performance: The role of organizational learning capability and innovation performance. Journal of Small Business Management, 51(4), 491-507. doi:10.1111/jsbm.12005

Amara, N., \& Landry, R. (2005). Sources of information as determinants of novelty of innovation in manufacturing firms: Evidence from the 1999 statistics Canada innovation survey. Technovation, 25(3), 245-259. doi:10.1016/ S0166-4972(03)00113-5

Amara, N., Landry, R., Becheikh, N., \& Ouimet, M. (2008). Learning and novelty of innovation in established manufacturing SMEs. Technovation, 28(7), 450-463. doi:10.1016/j.technovation.2008.02.001

Andersen, B. (1998). The evolution of technological trajectories 1890-1990. Structural Change and Economic Dynamics, 9(1), 5-34. doi:10.1016/S0954-349X(97)00036-2

Beckett, R. C., \& Vachhrajani, H. (2017). Transdisciplinary innovation: Connecting ideas from professional and user networks. Journal of Industrial Integration and Management, 2(4), 1750016. doi:10.1142/ S2424862217500166

Bergek, A., Berggren, C., Magnusson, T., \& Hobday, M. (2013). Technological discontinuities and the challenge for incumbent firms: Destruction, disruption or creative accumulation? Research Policy, 42(6-7), 1210-1224. doi:10.1016/j.respol.2013.02.009

Bian, Y. (1997). Bringing strong ties back in: Indirect ties, network bridges, and job searches in China. American Sociological Review, 62(3), 366-385. doi:10.2307/2657311

Cao, X., Chaudhry, S., \& Xu, L. (2019). Electronic Markets in Emerging Markets. Electronic Markets, 29(2), 151-152. doi:10.1007/s12525-019-00343-0

Chaudhry, S., Xu, L., \& Cao, X. (2018). Technological entrepreneurship and socio-economic change in BRIC countries. Technological Forecasting and Social Change, 135, 64-65. doi:10.1016/j.techfore.2018.07.054

Chen, H., \& Xie, F. (2018). How technological proximity affect collaborative innovation? An empirical study of China's Beijing-Tianjin-Hebei region. Journal of Management Analytics, 5(4), 287-308. doi:10.1080/232 70012.2018.1478329

Chen, H., Yao, M., \& Chong, D. (2019). Research on Institutional Innovation of China's Green Insurance Investment. Journal of Industrial Integration and Management, 4(1), 1950003. doi:10.1142/S2424862219500039

Chen, Y. (2016). Industrial information integration-A literature review 2006-2015. Journal of Industrial Information Integration, 2, 30-64. doi:10.1016/j.jii.2016.04.004

Christensen, C. M., \& Rosenbloom, R. S. (1995). Explaining the attacker's advantage: Technological paradigms, organizational dynamics, and the value network. Research Policy, 24(2), 233-257. doi:10.1016/00487333(93)00764-K

Dosi, G. (1982). Technological paradigms and technological trajectories: A suggested interpretation of the determinants and directions of technical change. Research Policy, 11(3), 147-162. doi:10.1016/00487333(82)90016-6

Dosi, G. (1988). Sources, procedures, and microeconomic effects of innovation. Journal of Economic Literature, $1120-1171$. 
Eiadat, Y., Kelly, A., Roche, F., \& Eyadat, H. (2008). Green and competitive? An empirical test of the mediating role of environmental innovation strategy. Journal of World Business, 43(2), 131-145. doi:10.1016/j. jwb.2007.11.012

Fan, Y. (2017). Research on factors influencing an individual's behavior of energy management: A field study in China. Journal of Management Analytics, 4(3), 203-239. doi:10.1080/23270012.2017.1310000

Fang, S., Zhu, Y., Xu, L., Zhang, J., Zhou, P., Luo, K., \& Yang, J. (2017). An Integrated System for Land Resources Supervision based on the IoT and Cloud Computing. Enterprise Information Systems, 11(1), $105-121$. doi:10.1080/17517575.2015.1086816

Feng, S., \& Xu, L. (1996). A Hybrid Knowledge-based System for Urban Development. Expert Systems with Applications, 10(1), 157-163. doi:10.1016/0957-4174(95)00042-9

Foster, R. N. (1986). Innovation: The attacker's advantage. Macmillan. doi:10.1007/978-3-322-83742-4

Fritsch, M., \& Lukas, R. (2001). Who co-operates on R\&D? Research Policy, 30(2), 297-312. doi:10.1016/ S0048-7333(99)00115-8

Gorkhali, A., \& Xu, L. (2016). Enterprise Application Integration in Industrial Integration: A Literature Review. Journal of Industrial Integration and Management, 1(4), 1650014. doi:10.1142/S2424862216500147

Gorkhali, A., \& Xu, L. (2017). Enterprise Architecture: A Literature Review. Journal of Industrial Integration and Management, 2(2), 1750009. doi:10.1142/S2424862217500099

Gorkhali, A., \& Xu, L. (2019). Enterprise Architecture, Enterprise Information Systems and Enterprise Integration: A Review Based on Systems Theory Perspective. Journal of Industrial Integration and Management, 4(2), 1950001. doi:10.1142/S2424862219500015

Granovetter, M. S. (1977). The strength of weak ties. In Social networks (pp. 347-367). Academic Press. doi:10.1016/B978-0-12-442450-0.50025-0

Hagedoorn, J., \& Cloodt, M. (2003). Measuring innovative performance: Is there an advantage in using multiple indicators? Research Policy, 32(8), 1365-1379. doi:10.1016/S0048-7333(02)00137-3

Hämäläinen, E., \& Inkinen, T. (2019). Industrial applications of big data in disruptive innovations supporting environmental reporting. Journal of Industrial Information Integration, 16, 100105. doi:10.1016/j.jii.2019.100105

Hobday, M., Rush, H., \& Bessant, J. (2004). Approaching the innovation frontier in Korea: The transition phase to leadership. Research Policy, 33(10), 1433-1457. doi:10.1016/j.respol.2004.05.005

Hsu, Y. H., \& Fang, W. (2009). Intellectual capital and new product development performance: The mediating role of organizational learning capability. Technological Forecasting and Social Change, 76(5), 664-677. doi:10.1016/j.techfore.2008.03.012

Hu, B., \& Li, X. F. (2013). Study on the dynamic evolution and operation of firm's ecosystem in the context of complicated changing environment. Tongji University Press.

Hwang, V., \& Mabogunje, A. (2013). The new economics of innovation ecosystems. Stanford Social Innovation Review, 8(6), 123-125.

Jerez-Gomez, P., Cespedes-Lorente, J., \& Valle-Cabrera, R. (2005). Organizational learning capability: A proposal of measurement. Journal of Business Research, 58(6), 715-725. doi:10.1016/j.jbusres.2003.11.002

Kaminski, P. C., de Oliveira, A. C., \& Lopes, T. M. (2008). Knowledge transfer in product development processes: A case study in small and medium enterprises (SMEs) of the metal-mechanic sector from Sao Paulo, Brazil. Technovation, 28(1-2), 29-36. doi:10.1016/j.technovation.2007.07.001

Katila, R., \& Ahuja, G. (2002). Something old, something new: A longitudinal study of search behavior and new product introduction. Academy of Management Journal, 45(6), 1183-1194.

Kemp, R. (1997). Environmental policy and technical change. Edward Elgar Publishing.

Kumar, A., \& Chanda, U. (2018). Two-warehouse inventory model for deteriorating items with demand influenced by innovation criterion in growing technology market. Journal of Management Analytics, 5(3), 198-212. doi: $10.1080 / 23270012.2018 .1462111$ 
Lei, D., Slocum, J. W., \& Pitts, R. A. (1999). Designing organizations for competitive advantage: The power of unlearning and learning. Organizational Dynamics, 27(3), 24-38. doi:10.1016/S0090-2616(99)90019-0

Lei, J., Lin, B., \& Sha, S. (2016). Catching-up pattern among countries in science-based industries: A case study in pharmaceutical industry. Journal of Industrial Integration and Management, 1(1), 1650004. doi:10.1142/ S2424862216500044

Lei, J., Liu, Y., Qi, Y., \& Zhang, Q. (2019). 40 Years of Technological Innovation in China: A Review of the Four-Stage Climbing Track. Journal of Industrial Integration and Management, 4(3), 1950008. doi:10.1142/ S2424862219500088

Lei, J., Zhang, Q., \& Qi, Y. (2020). Innovation-led Development: The Logic of China's Economic Development. Journal of Industrial Integration and Management, 5(1), 1-11. doi:10.1142/S2424862220500013

Leonard-Barton, D. (1992). Core capabilities and core rigidities: A paradox in managing new product development. Strategic Management Journal, 13(S1), 111-125. doi:10.1002/smj.4250131009

Li, L. (2013). The path to Made-in-China: How this was done and future prospects. International Journal of Production Economics, 146(1), 4-13. doi:10.1016/j.ijpe.2013.05.022

Li, L. (2018). China's manufacturing locus in 2025: With a comparison of "Made-in-China 2025" and "Industry 4.0". Technological Forecasting and Social Change, 135, 66-74. doi:10.1016/j.techfore.2017.05.028

Li, L. (2020). Education supply chain in the era of Industry 4.0. Systems Research and Behavioral Science, 37(4), 579-592. doi:10.1002/sres.2702

Li, L., Markowski, E., Markowski, C., \& Xu, L. (2008). Assessing the Effects of Manufacturing Infrastructure Preparation prior to Enterprise Information Systems Implementation. International Journal of Production Research, 46(6), 1645-1665. doi:10.1080/00207540600898064

Li, L., \& Xu, L. (1991). An Integrated Information System for the Intervention and Prevention of AIDS. International Journal of Bio-Medical Computing, 29(3-4), 191-206. doi:10.1016/0020-7101(91)90037-F PMID:1778635

Li, L., \& Zhou, H. (2013). Manufacturing practices in China. International Journal of Production Economics, l(146), 1-3. doi:10.1016/j.jpe.2013.09.006

Li, M., Asunka, B., Su, J., Hu, C., Wen, M., \& Wu, Y. (2020). Sustaining Corporate Innovation through UniversityIndustry Collaborative Research: Evidence from the Jiangsu University of China. Journal of Industrial Integration and Management, 5(2), 235-252. doi:10.1142/S2424862220500025

Li, W., Chang, J., Wang, M. J., Zhu, X., \& Jin, A. (2014). Innovation 3.0 and innovation ecosystem. Studies in Science of Science, 32(12), 1761-1770.

Liang, D. P., Liu, T. S., \& Li, Y. J. (2015). Correlation between environmental attention and firm value based on perspective of environmental policy. Science \& Technology Progress and Policy, 9, 1-6.

Liefner, I., Hennemann, S., \& Xin, L. (2006). Cooperation in the innovation process in developing countries: Empirical evidence from Zhongguancun, Beijing. Environment \& Planning A, 38(1), 111-130. doi:10.1068/ a37343

Lu, Y., \& Zheng, X. (2020). 6G: A Survey on Technologies, Scenarios, Challenges, and the Related Issues. Journal of Industrial Information Integration, 19, 100158. doi:10.1016/j.jii.2020.100158

Mallén, F., Chiva, R., Alegre, J., \& Guinot, J. (2016). Organicity and performance in excellent HRM organizations: The importance of organizational learning capability. Review of Managerial Science, 10(3), 463-485. doi:10.1007/ s11846-014-0164-2

Monticolo, D., Lahoud, I., \& Barrios, P. C. (2020). OCEAN: A multi agent system dedicated to knowledge management. Journal of Industrial Information Integration, 17, 100124. doi:10.1016/j.jii.2019.100124

Nieto, M. J., \& Santamaría, L. (2007). The importance of diverse collaborative networks for the novelty of product innovation. Technovation, 27(6-7), 367-377. doi:10.1016/j.technovation.2006.10.001 
Niu, N., Xu, L., \& Bi, Z. (2013). Enterprise Information Systems Architecture-Analysis and Evaluation. IEEE Transactions on Industrial Informatics, 9(4), 2147-2154. doi:10.1109/TII.2013.2238948

Niu, N., Xu, L., Cheng, J., \& Niu, Z. (2014). Analysis of Architecturally Significant Requirements for Enterprise Systems. IEEE Systems Journal, 8(3), 850-857. doi:10.1109/JSYST.2013.2249892

Nwankpa, J., \& Roumani, Y. (2014). Understanding the link between organizational learning capability and ERP system usage: An empirical examination. Computers in Human Behavior, 33, 224-234. doi:10.1016/j. chb.2014.01.030

Olin, T., \& Shani, A. B. (2003). NPD as a sustainable work process in a dynamic business environment. $R \& D$ Management, 33(1), 1-13. doi:10.1111/1467-9310.00277

Padmanathan, K., Govindarajan, U., Ramachandaramurthy, V. K., \& Jeevarathinam, B. (2018). Integrating solar photovoltaic energy conversion systems into industrial and commercial electrical energy utilization-A survey. Journal of Industrial Information Integration, 10, 39-54. doi:10.1016/j.jii.2018.01.003

Pan, S. T., \& Cai, N. (2010). Dimension exploitation and measurement of tie strength in enterprise network. China Soft Science, 5, 108-115.

Park, S. H., \& Luo, Y. (2001). Guanxi and organizational dynamics: Organizational networking in Chinese firms. Strategic Management Journal, 22(5), 455-477. doi:10.1002/smj.167

Pavitt, K. (1986). Technology, innovation and strategic management. Strategic management research: A European perspective, 171-190.

Peng, M. W., \& Luo, Y. (2000). Managerial ties and firm performance in a transition economy: The nature of a micro-macro link. Academy of Management Journal, 43(3), 486-501.

Porter, M., \& Van der Linde, C. (1995). Green and competitive: ending the stalemate. The Dynamics of the eco-efficient economy: Environmental regulation and competitive advantage, 33.

Porter, M. E. (1991). Towards a dynamic theory of strategy. Strategic Management Journal, 12(S2), 95-117. doi: $10.1002 / \mathrm{smj} .4250121008$

Qi, G. Y., Shen, L. Y., Zeng, S. X., \& Jorge, O. J. (2010). The drivers for contractors' green innovation: An industry perspective. Journal of Cleaner Production, 18(14), 1358-1365. doi:10.1016/j.jclepro.2010.04.017

Qian, X. H., Yang, Y. F., \& Xu, W. L. (2010). Firm network location: Absorptive capacity and innovation performance. Guanli Shijie, 5, 118-129.

Rennings, K., Markewitz, P., \& Vögele, S. (2013). How clean is clean? Incremental versus radical technological change in coal-fired power plants. Journal of Evolutionary Economics, 23(2), 331-355. doi:10.1007/s00191010-0198-9

Rogers, E. M. (2003). Diffusion of innovations. The Free Press.

Rowley, T., Behrens, D., \& Krackhardt, D. (2000). Redundant governance structures: An analysis of structural and relational embeddedness in the steel and semiconductor industries. Strategic Management Journal, 21(3), 369-386. doi:10.1002/(SICI)1097-0266(200003)21:3<369::AID-SMJ93>3.0.CO;2-M

Rupčić, N., Majić, T., \& Stjepandić, J. (2020). Emergence of Business Ecosystems by Transformation of Platforms Through the Process of Organizational Learning. Journal of Industrial Integration and Management, 5(2), 181-203. doi:10.1142/S2424862220500086

Salmelin, B. (2013). Innovation in Horizon 2020-Reflections from Open Innovation 2.0 paradigm. Open Innovation 2.0 Conference, Brussels, Belgium.

Sammarra, A., \& Biggiero, L. (2008). Heterogeneity and specificity of Inter-Firm knowledge flows in innovation networks. Journal of Management Studies, 45(4), 800-829. doi:10.1111/j.1467-6486.2008.00770.x

Santos-Vijande, M. L., Sanzo-Perez, M. J., Alvarez-Gonzalez, L. I., \& Vazquez-Casielles, R. (2005). Organizational learning and market orientation: Interface and effects on performance. Industrial Marketing Management, 34(3), 187-202. doi:10.1016/j.indmarman.2004.08.004 
Schaefer, A. (2004). Corporate sustainability-integrating environmental and social concerns? Corporate Social Responsibility and Environmental Management, 11(4), 179-187. doi:10.1002/csr.70

Schumpeter, J. A. (1942). Capitalism, Socialism\& Democracy (5th ed.). Routledge.

Schumpeter, J. A. (1982). The theory of economic development: An inquiry into profits, capital, credit, interest, and the business cycle (1912/1934). Transaction Publishers.

Sharma, S. K., \& Chanda, U. (2017). Developing a Bayesian belief network model for prediction of R\&D project success. Journal of Management Analytics, 4(3), 321-344. doi:10.1080/23270012.2017.1304291

Sheng, S., Zhou, K. Z., \& Li, J. J. (2011). The effects of business and political ties on firm performance: Evidence from China. Journal of Marketing, 75(1), 1-15. doi:10.1509/jm.75.1.1

Slater, S. F., \& Narver, J. C. (1995). Market orientation and the learning organization. Journal of Marketing, 59(3), 63-74. doi:10.1177/002224299505900306

Sperling, D., \& Gordon, D. (2009). Two Billion Cars. Oxford University Press.

Takala, M. (1991). Environmental awareness and human activity. International Journal of Psychology, 26(5), 585-597. doi:10.1080/00207599108247146

Tan, W., Xu, W., Yang, F., Xu, L., \& Jiang, C. (2013). A Framework for Service Enterprise Workflow Simulation with Multi-Agents Cooperation. Enterprise Information Systems, 7(4), 523-542. doi:10.1080/17517575.2012 .660503

Tan, W., Xu, Y., Xu, W., Xu, L., Zhao, X., Wang, L., \& Fu, L. (2010). A Methodology toward Manufacturing Grid-based Virtual Enterprise Operation Platform. Enterprise Information Systems, 4(3), 283-309. doi:10.10 80/17517575.2010.504888

Tether, B. S. (2002). Who co-operates for innovation, and why: An empirical analysis. Research Policy, 31(6), 947-967. doi:10.1016/S0048-7333(01)00172-X

Utterback, J. M., \& Abernathy, W. J. (1975). A dynamic model of process and product innovation. Academic Press.

Viriyasitavat, W., Xu, L., \& Viriyasitavat, W. (2014). A New Approach for Compliance Checking in Service Workflows. IEEE Transactions on Industrial Informatics, 10(2), 1452-1460. doi:10.1109/TII.2014.2301143

Wang, C., Xu, L., Liu, X., \& Qin, X. (2005). ERP Research, Development and Implementation in China: An Overview. International Journal of Production Research, 43(18), 3915-3932. doi:10.1080/13629390500124556

Wang, C., Xu, L., \& Peng, W. (2007). Conceptual Design of Remote Monitoring and Fault Diagnosis Systems. Information Systems, 32(7), 996-1004. doi:10.1016/j.is.2006.10.004

Wang, W., Niu, N., Alenazi, M., \& Xu, L. (2019). In-Place Traceability for Automated Production Systems: A Survey of PLC and SysML Tools. IEEE Transactions on Industrial Informatics, 15(6), 3155-3162. doi:10.1109/ TII.2018.2878782

Windrum, P. (2004). Leveraging technological externalities in complex technologies: Microsoft's exploitation of standards in the browser wars. Research Policy, 33(3), 385-394. doi:10.1016/j.respol.2003.09.002

Wipulanusat, W., Panuwatwanich, K., Stewart, R. A., Arnold, S. L., \& Wang, J. (2020). Bayesian network revealing pathways to workplace innovation and career satisfaction in the public service. Journal of Management Analytics, 7(2), 253-280. doi:10.1080/23270012.2020.1749900

Wu, S., Xu, L., \& He, W. (2009). Industry-oriented Enterprise Resource Planning. Enterprise Information Systems, 3(4), 409-424. doi:10.1080/17517570903100511

Xiao, C., \& Dunlap, R. E. (2007). Validating a comprehensive model of environmental concern cross-nationally: A US-Canadian comparison. Social Science Quarterly, 88(2), 471-493. doi:10.1111/j.1540-6237.2007.00467.x

Xiao, Y., Tylecote, A., \& Liu, J. (2013). Why not greater catch-up by Chinese firms? The impact of IPR, corporate governance and technology intensity on late-comer strategies. Research Policy, 42(3), 749-764. doi:10.1016/j. respol.2012.11.005 
Xie, X. M., \& Xu, M. Y. (2014). Collaborative innovation mechanism, collaborative innovation atmosphere and innovation performance: Taking collaborative networks as the mediator variable. Science Research Management, (12), 2.

$\mathrm{Xu}$, L. (2011). Enterprise Systems: State-of-the-Art and Future Trends. IEEE Transactions on Industrial Informatics, 7(4), 630-640. doi:10.1109/TII.2011.2167156

$\mathrm{Xu}, \mathrm{L}$. (2013). Introduction: Systems Science in Industrial Sectors. Systems Research and Behavioral Science, 30(3), 211-213. doi:10.1002/sres.2186

$\mathrm{Xu}$, L. (2014). Engineering Informatics: State of the Art and Future Trends. Frontiers of Engineering Management, 1(3), 270-282. doi:10.15302/J-FEM-2014038

$\mathrm{Xu}, \mathrm{L}$. (2016). Inaugural Issue Editorial. Journal of Industrial Information Integration, 1, 1-2. doi:10.1016/j. jii.2016.04.001

$\mathrm{Xu}$, L. (2020). The Contribution of Systems Science to Industry 4.0. Systems Research and Behavioral Science, 37(4), 618-631. doi:10.1002/sres.2705

Xu, L., Cai, L., Zhao, S., \& Ge, B. (2016). Editorial: Inaugural Issue. Journal of Industrial Integration and Management, 1(1), 1601001. doi:10.1142/S2424862216010016

Xu, L., Tan, W., Zhen, H., \& Shen, W. (2008). An Approach to Enterprise Process Dynamic Modeling Supporting Enterprise Process Evolution. Information Systems Frontiers, 10(5), 611-624. doi:10.1007/s10796-008-9114-3

$\mathrm{Xu}$, L., \& Viriyasitavat, W. (2014). A Novel Architecture for Requirement-oriented Participation Decision in Service Workflows. IEEE Transactions on Industrial Informatics, 10(2), 1478-1485. doi:10.1109/ TII.2014.2301378

Xu, L., Wang, C., Bi, Z., \& Yu, J. (2014). Object-Oriented Templates for Automated Assembly Planning of Complex Products. IEEE Transactions on Automation Science and Engineering, 11(2), 492-503. doi:10.1109/ TASE.2012.2232652

Xu, L., Wang, C., Luo, X., \& Shi, Z. (2006). Integrating Knowledge Management and ERP in Enterprise Information Systems. Systems Research and Behavioral Science, 23(2), 147-156. doi:10.1002/sres.750

Yang, Y., Chen, H., Zhang, Q., \& Lei, J. (2018). The Commercialization of University and Research Institutes' Science-Based Innovations: The Four Successful Chinese Cases. Journal of Industrial Integration and Management, 3(03), 1850013. doi:10.1142/S2424862218500136

Yuan, P., Liu, Y. B., \& Li, X. S. (2015). The relationship among interaction orientation, customer participated innovation and innovation performance. Science Research Management, 36(8), 52-59.

Zeng, S. X., Xie, X. M., \& Tam, C. M. (2010). Relationship between cooperation networks and innovation performance of SMEs. Technovation, 30(3), 181-194. doi:10.1016/j.technovation.2009.08.003

Zhang, J., \& Wong, P. K. (2008). Networks vs. market methods in high-tech venture fundraising: The impact of institutional environment. Entrepreneurship and Regional Development, 20(5), 409-430. doi:10.1080/08985620801886406

Zhang, Q., Yang, Y., Qi, Y., \& Lei, J. (2018). Science-based innovation in China: A case study of artemisinin from laboratory to the market. Journal of Industrial Integration and Management, 3(2), 1850011. doi:10.1142/ S2424862218500112

Zhang, Y., Li, Z., Xu, L., \& Wang, J. (2011). A New Method for Automatic Synthesis of Tolerances for Complex Assemblies based on Polychromatic Sets. Enterprise Information Systems, 5(3), 337-358. doi:10.1080/17517 575.2011 .593004

Zhao, F., \& Zeng, G. P. (2014). Innovation ecosystem under multiple perspectives. Studies in Science of Science, 32(12), 1781-1796. 
Yu Sun received his Bachelor degree, master, and PhD from Jilin University in 2007, 2010, and 2016, respectively. He has been working at FAW as an economist (2010-2016), and as a research associate (2017-now) in Hangzhou Dianzi University. Dr. Yu Sun has engaged in several foundation items, including National Natural Science Foundations, Zhejiang Natural Science Foundation, etc., and published several papers and reports. Dr. Yu Sun is now one of the main organizers of Chinese Management Science Forum, and has successfully organized several forums during last years. He is also a member fellow of MIIT Thinktanks, serving for Ministry of Industry and Information Technology of China and industrial enterprises.

Ling Li is the Chair of the Department of Information Technology and Decision Sciences, Old Dominion University, USA. She is eminent scholar and university professor. She has published over 140 peer-refereed research articles in high quality journals, three single-authored books on supply chain management and logistics, encyclopedia articles, business cases, conference proceeding papers, and book chapters. Dr. Li has been recognized with numerous awards for her teaching excellence, scholarly contribution, and service commitment. She serves as the First Secretary (officer) of International Federation for Information Processing and serves area editor, associate editor and editorial board member of several journals.

Yong Chen is an Assistant Professor in A. R. Sanchez, Jr. School of Business, Texas A\&M International University. He received his Ph.D. from Old Dominion University in Virginia. His research interests are in the area of Internet of Things, big data, social media, mobile payment, and E-business.

Mikhail Yu Kataev graduated from Tomsk State University in 1984, received a PhD in Physics and Mathematics in 1993 and a Doctor of Technical Sciences in 2002. Currently works at the Tomsk State University of Control Systems and Radioelectronics at the Faculty of Control Systems. He is the head of the scientific and educational laboratory "data and image processing", is responsible for the master's program "information and computing technologies". He is an academician of the International Academy of Informatization, academician of the Academy of Higher Education, academic adviser of the Russian Engineering Academy, expert of the Ministry of Education and Science of the Russian Federation. 